Natural History

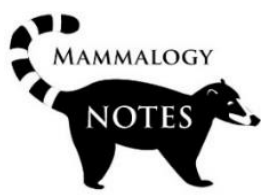

\title{
Frugivory and Seed predation of Jacaratia spinosa (Caricaceae) by Sumichrast's Vesper Rat, Nyctomys sumichrasti (Rodentia: Cricetidae)
}

\author{
Diego Salas-Solano ${ }^{1 *(D)}$, David Villalobos-Chaves ${ }^{2}$ (D)
}

1 Veragua Foundation, 70102, Limón, Costa Rica.

2 Department of Biology, University of Washington, Seattle, WA 98195, USA.

*Correspondence: dsalas@veraguarainforest.com

\begin{abstract}
Animal-plant interactions are ubiquitous and critical for tropical ecosystem functioning. Neotropical rodents perform key ecosystem functions such as seed dispersal and predation, however few information is available regarding their ecological interactions. Here, we reported the interaction between the Sumichrast's Vesper Rat, Nyctomys sumichrasti, and the plant Jacaratia spinosa in the Central Caribbean of Costa Rica. Rodents were observed feeding on the flesh and seeds of the plants. Natural history observations such as this are critical to the knowledge on the feeding links of poorly known Neotropical rodents.
\end{abstract}

Key words: Animal-plant interaction, Costa Rica, Veragua Rainforest, fleshy fruits, Neotropical rodents.

\section{Resumen}

Las interacciones animal-planta son ubicuas y críticas para el funcionamiento de los ecosistemas tripicales. Los roedores neotropicales desempeñan funciones clave del ecosistema, como la dispersión de semillas y la depredación, sin embargo hay poca información disponible sobre sus interacciones ecológicas. Aquí, informamos sobre la interacción entre la rata Nyctomys sumichrasti y la planta Jacaratia spinosa en el Caribe Central de Costa Rica. Se observaron roedores alimentándose de la pulpa y semillas de las plantas. Las observaciones de la historia natural como esta son fundamentales para generar y aumentar el conocimiento la dieta de los roedores neotropicales poco conocidos.

Palabras clave: Interacción animal-planta, Costa Rica, Bosque lluvioso Veragua, frutos carnosos, roedores Neotropicales.

Animals and plants interact in diverse and multiple ways reflecting the complexity of natural histories of partner species (Jordano 2016). In tropical ecosystems, for example, where up to $90 \%$ of plants interact with vertebrates (Jordano 2001), understanding the nature and extent of these links and their outcomes can help us to elucidate the evolution of species interactions, as well as the potential implications of the loss of components in 
the ecological networks (Carreira et al. 2020). In this sense, despite is well known that many seeds of tropical plants are dispersed and/or predated by vertebrates (Howe 1986; Jordano 2000), detailed information on these interactions are scarce and what disperse and/or predate what is unknown for many plant species. Among mammals, for example, growing evidence suggests that small rodents may play antagonistic roles, either dispersing (Sahley et al. 2016) or predating (Janzen 1982; Leiser-Miller et al. 2019) seeds of multiple plant species. In hyperdiverse forests, where many animal-plant interactions are unknown, are rapidly disappearing or changing due to factors such as habitat loss and/or defaunation (Cardillo et al. 2008), documenting these interactions may help us to understand and quantify the role of small vertebrates on ecological interactions with implication on plant population dynamics (Hulme 1998).

The Sumichrast's Vesper Rat, Nyctomys sumichrasti (Saussure 1860) is a medium-sized, nocturnal, and arboreal Neotropical rodent species distributed from Jalisco and Veracruz, Mexico, except Yucatán Peninsula, to eastern Panama (Reid 2009). It is mainly recognized by its orange upperparts, its creamy white underparts, large eyes surrounded by dark eye rings, and a dark and long-haired tail with a pronounced terminal tuft (Reid 2009). Dietary information suggests that Nyctomys sumichrasti feeds mainly on fruits, seeds, and leaves (Genoways and Jones 1972; Eisenberg 1989; Ceballos 1990; Timm and Vriesendorp 2003; Hunt et al. 2004; Bessesen and Saborio-R 2009; Villalobos-Chaves et al. 2020) and despite is one of the most well-known Neotropical rodent species, basic aspects of its natural history, including its ecological roles are poorly understood.

Dietary information of $\mathrm{N}$. sumichrasti is scarce and available data suggest that this species can eat seeds in captivity. However, information about seed predation is limited to these observations (Hunt et al. 2004) or assumptions by other authors (Villalobos-Chaves et al. 2020). Here, we reported on the interaction of the Sumichrast's Vesper Rat with the fruits and seeds of the Neotropical plant Jacaratia spinosa (Figure 1a). Observations were made at Veragua Rainforest $\left(09^{\circ} 55^{\prime} 30^{\prime \prime} \mathrm{N}, 083^{\circ} 11^{\prime} 28^{\prime \prime} \mathrm{W}, \mathrm{WGS} 84 ; 420\right.$ masl), located in the Central Caribbean of Costa Rica, on the northern edge of the Matama mountains, in the Talamanca mountain range. This private reserve comprises mature forest, a successional forest at different stages of regeneration, open areas, small gardens, and anthropogenic structures (Salas-Solano et al. 2020). On two consecutive nights on August 2018, we observed adult individual Sumichrast's Vesper Rats of unknown sex visiting the ripe fruits and predating the seeds of a J. spinosa tree (Caricaceae). Observations were performed from $19 \mathrm{~h} 37$ to $19 \mathrm{~h} 56$ (first day) and from $18 \mathrm{~h} 58$ to $19 \mathrm{~h} 06$ (second day), approximately at $3 \mathrm{~m}$ high on the tree. During these times, the rodents were observed eating the inside of ripe fruits, different each day, and photographed/filmed in the second night to document the feeding interaction. Animals used their mouth to take portions of the flesh and seeds with each chew (Figure 1b). Once extracted, the rodents released their front legs from the fruit and use their front feet to manipulate and chew the seeds one by one (Figure 1c). While doing this, a considerable proportion of the removed flesh of the fruit fell off to the ground, including some whole seeds and the predated ones (Figure 1d, video S1). Based on the observations, only one fruit was exploited by the rodents per night and no other animal was observed consuming the flesh nor the seeds of the J. spinosa tree. Lastly, and as documented by other authors (Timm and Vriesendorp 2003; Villalobos-Chaves et al. 2020), while predating on the seeds of J. spinosa, $N$. sumichrasti were always using its long tail and hind feet to support itself. The use of these morphological traits to move and stabilize themselves while foraging may allow this species to exploit resources on other strata not available for other rodents (Villalobos-Chaves et al. 2020). 


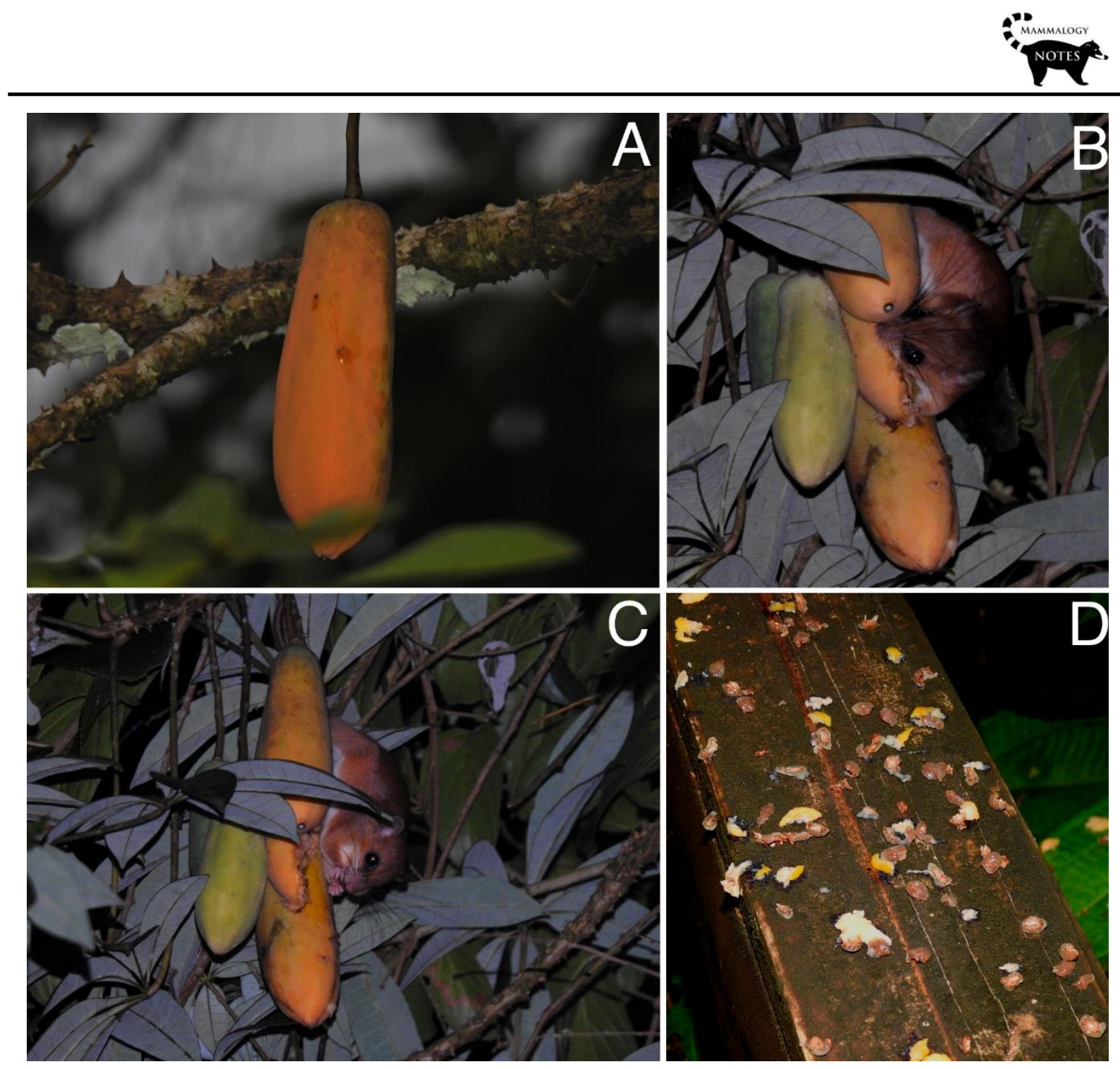

FIGURE 1. Sumichstart's Vesper Rat, Nyctomys sumichrasti, feeding on fruits and predating on seeds of Jacaratia spinosa at Veragua Rainforest, Costa Rica. (A) Details of a ripe fruit of J. spinosa. (B) An individual N. sumichrasti taking portions of the fruit of J. spinosa. (C) Details of manipulation and later seed predation of the seeds of J. spinosa. (D) Predated seeds (mostly) and small portions of flesh dropped by the rodents during the feeding process.

J. spinosa (Caricaceae) is a widespread tree distributed throughout the Neotropical region from Guatemala to northeast Argentina (Carvalho and Renner 2012). Through its distribution J. spinosa fruits are attractive and nutritive items documented in the diet of the lowland tapir Tapirus terrestris, the opossum Didelphis aurita, the tortoise Chelonoidis denticulate, the black and white tegu Tupinambis merianae, peccaries, monkeys and birds (Pack et al. 1999; Henry et al. 2000; Riba-Hernández et al. 2003; Felton et al. 2008; Genovese et al. 2008; Jerozolimski et al. 2009; Casella 2011; Ramos-Martınez et al. 2012; Carvalho and Renner 2012; Carvalho et al. 2015; Bello et al. 2017). However, this is the first time a rodent species is detected consuming the flesh of the $\mathrm{J}$. spinosa fruits and predating their seeds. As been documented before (Villalobos-Chaves et al. 2020), our observations suggest that $N$. sumichrasti might be an opportunistic visitor of J. spinosa. In addition, given that damaged seeds were dropped on the ground during the feeding process (Figure 1d, Video S1), we suggest that future efforts are needed to better understand the extent of this 
ecological interaction. Natural history observations like this are key to understand the role of species interacting with their plant partners. This kind of observation increase the knowledge of the feeding links, frugivore networks, and food webs of complex and highly diverse Neotropical ecosystems.

\section{ACKNOWLEDGEMENTS}

We acknowledge Veragua Rainforest and Veragua Foundation for promoting research and conservation.

\section{REFERENCES}

Bello, C., Galetti, M., Montan, D., Pizo, M.A., Mariguela, T.C., Culot, L., Bufalo, F., Labecca, F., Pedrosa, F., Constantini, R., Emer, C., Silva, W.R., da Silva, F.R., Ovaskainen, O., Jordano, P., 2017. Atlantic frugivory: a plant-frugivore interaction data set for the Atlantic Forest. Ecology. 98 (6), 17291729. https:// doi.org/10.1002/ecy.1818

Bessesen, B.L., Saborío-R, G., 2009. First report of Vesper rat, Nyctomys sumichrasti (Rodentia: Muridae), feeding on palm fruits. Brenesia. 71-72, 73-76.

Cardillo, M., Mace, G.M., Gittleman, J.L., Jones, K.E., Bielby, J., Purvis, A., 2008. The predictability of extinction: biological and external correlates of decline in mammals. Proceedings of the Royal Society B. 275 (1641), 1441-1448. https:// doi.org/10.1098/rspb.2008.0179

Carreira, D. C., Dáttilo, W., Bruno, D. L., Percequillo, A. R., Ferraz, K. M., \& Galetti, M. (2020). Small vertebrates are key elements in the frugivory networks of a hyperdiverse tropical forest. Scientific Reports. 10(1), 1-11. https:/ / doi.org/10.1038/s41598-020-67326-6

Carvalho, F.A., Renner, S.S., 2012. A dated phylogeny of the papaya family (Caricaceae) reveals the crop's closest relatives and the family's biogeographic history. Molecular Phylogenetics and Evolution. 65 (1), 46-53. https:// doi.org/10.1016/j.ympev.2012.05.019

Carvalho, F.A., Filer, D., Renner, S.S., 2015. Taxonomy in the electronic age and an e-monograph of the papaya family (Caricaceae) as an example. Cladistics. 31 (3), 321-329. https:// doi.org/10.1111/cla.12095

Casella, J., 2011. Diet of Didelphis aurita and Micoureus paraguayanus and the fruit availability in a semideciduous Atlantic forest in Southern Brazil. Neotropical Biololgy and Conservation. 6 (2), 85-93. https://doi.org/10.4013/nbc.2011.62.03

Ceballos, G., 1990. Comparative natural history of small mammals from tropical forests in Western Mexico. Journal of Mammalogy. 71 (2): 263-266. https:// doi.org/10.2307/1382182

Eisenberg, J.F., 1989. Mammals of the Neotropics. The Northern Neotropics: Panama, Colombia, Venezuela, Guyana, Suriname, French Guiana. University of Chicago Press, Illinois.

Felton, A.M., Felton, A., Wood, J.T., Lindenmayer, D.B., 2008. Diet and feeding ecology of Ateles chamek in a Bolivian semihumid forest: the importance of Ficus as a staple food resource. International Journal of Primatology. 29(2), 379-403. https:// doi.org/10.1007/s10764-008-9241-1

Genoways, H. H., Jones Jr, J. K. (1972). Mammals from southwestern North Dakota. Occasional Papers of the Museum of Texas Tech University. 3, 1-22.

Genovese, M. I., Da Silva Pinto, M., De Souza Schmidt Gonçalves, A.E., Lajolo, F.M. 2008. Bioactive compounds and antioxidant capacity of exotic fruits and commercial frozen pulps from Brazil. Food Science and Technology International. 14(3), 207-214. https:// doi.org/10.1177/1082013208092151

Henry, O., Feer, F., Sabatier, D., 2000. Diet of the lowland tapir (Tapirus terrestris L.) in French Guiana. Biotropica. 32(2), 364-368. https:// doi.org/10.1111/j.1744-7429.2000.tb00480.x 
Hulme, P.E., 1998. Post-dispersal seed predation: Consequences for plant demography and evolution. Perspectives in Plant Ecology, Evolution and Systematics. 1 (1), 32-46. https:// doi.org/10.1078/1433-8319-00050

Hunt, J. L., Morris, J. E., \& Best, T. L. (2004). Nyctomys sumichrasti. Mammalian Species. 754, 1-6. https:// doi.org/10.1644/754

Janzen, D.H., 1982. Seed removal from fallen guanacaste fruits (Enterolobium cyclocarpum) by spiny pocket mice (Liomys salvini). Brenesia. 19 (20), 425-429.

Jerozolimski, A., Ribeiro, M.B.N., Martins, M. 2009. Are tortoises important seed dispersers in Amazonian forests? Oecologia. 161 (3), 517-528. https:// doi.org/10.1007/s00442-009-1396-8

Jordano, P., 2001. Fruits and frugivory. In: Fenner, M. (Ed.), Seeds: the ecology of regeneration in plant commuties. CABI Publishing, Wallingford.

Jordano, P., 2016. Chasing Ecological Interactions. PLoS Biology. 14(9): e1002559. https:/ / doi.org/10.1371/journal.pbio.1002559

Leiser-Miller, L.B., Kaliszewska, Z.A., Villalobos-Chaves, D., Santana, S.E., 2019. A pygmy rice rat eats a peppery snack. Frontiers in Ecology and the Environment. 17(7), 369 - 369 https:// doi.org/10.1002/fee.2096.

Pack, K.S., Henry, O., Sabatier, D., 1999. The insectivorous-frugivorous diet of the golden-handed tamarin (Saguinus midas midas) in French Guiana. Folia Primatologica. 70(1), 1-7. https://doi.org/10.1159/000021668

Ramos-Martínez, E.M., Herrera-Ramírez, A.C., Badillo-Corona, J.A., Garibay-Orijel, C., González-Rábade, N., del Carmen Oliver-Salvador, M., 2012. Isolation of cDNA from Jacaratia mexicana encoding a mexicain-like cysteine protease gene. Gene. 502 (1), 60-68. https:// doi.org/10.1016/j.gene.2012.04.018

Reid, F.A., 2009. A Field Guide to the Mammals of Central America and Southeast Mexico. 2 ed. Oxford University Press, New York, USA, pp. 218-219.

Riba-Hernández, P., Stoner, K.E., Lucas, P.W., 2003. The sugar composition of fruits in the diet of spider monkeys (Ateles geoffroyi) in tropical humid forest in Costa Rica. Journal of Tropical Ecology. 19 (6), 709-716. https:// doi.org/10.1017/S0266467403006102

Sahley, C.T., Cervantes, K., Salas, E., Paredes, D., Pacheco, V., Alonso, A., 2016. Primary seed dispersal by a sigmodontine rodent assemblage in a Peruvian montane forest. Journal of Tropical Ecology. 32 (02), 125-134. https:// doi.org/10.1017/S0266467416000043

Salas-Solano, D., Moras, L.M., Tavares, V.D.C., Rodriguez-Herrera, B., 2020. Extension of the known geographic distribution of Greenhall's Dog-faced Bat, Cynomops greenhalli Goodwin, 1958 (Chiroptera, Molossidae): first records in Costa Rica. Check List. 16 (4), 871-875. https:// doi.org/10.15560/16.4.871

Timm, R.M., Vriesendorp, C., 2003. Observations on feeding behavior in the vespermouse, Nyctomys sumichrasti. Mammalian Biology. 68 (2), 126-128. https://doi.org/10.1078/1616-5047-00073

Villalobos-Chaves, D., Jiménez, J.E. \& Acosta-Chaves, V. 2020. Assembling rodent's feeding links: Observation of Sumichrast's Vesper Rat, Nyctomys sumichrasti (Rodentia: Cricetidae), feeding on fruits of Tabernaemontana glabra (Apocynaceae). Food Webs. 24, e00156. https:// doi.org/10.1016/j.fooweb.2020.e00156

Editor: Diego J. Lizcano

Received 2021-04-08

Revised 2021-05-10

Accepted 2021-06-04

Published 2021-06-15 